\title{
A “outra” América e os soviéticos durante a Guerra das Malvinas no Jornal do Brasil
}

\author{
Otávio Massaro \\ Graduado em História pela Universidade Federal de Alfenas (Unifal-MG)
}

\section{Resumo}

Objetiva-se, neste artigo, discutir como o Jornal do Brasil se manifestou em relação à postura de demais países da América Latina diante da Guerra das Malvinas, bem como analisar a maneira que o periódico avaliou a possibilidade de a União Soviética intervir no continente e no conflito em benefício da Argentina. Como a maioria dos países sul-americanos se posicionou explicitamente a favor das reivindicações argentinas, o jornal atualizou argumentos culturalistas que reforçavam as diferenças entre brasileiros e demais integrantes do continente americano de origem hispânica, posto que naquele momento a adoção pelo governo brasileiro da neutralidade de caráter imperfeito foi considerada, pelo Jornal do Brasil, a política mais adequada.

Palavras-chave Guerra das Malvinas - Jornal do Brasil - Soviéticos - Latino-americanos.

\begin{abstract}
The aim of this article is to discuss how the Jornal do Brasil manifested itself in relation to the stance of other Latin American countries in the face of the War of Malvinas, as well as analyzing how the journal evaluated the possibility of the Soviet Union intervening on the continent and conflict for the benefit of Argentina. As most South American countries had explicitly positioned themselves in favor of Argentine claims, the newspaper updated culturalist arguments that reinforced the differences between Brazilians and other members of the American continent of Hispanic origin, since the adoption by the Brazilian government of a neutrality of an imperfect nature was considered, by the Jornal do Brasil, the most appropriate policy.
\end{abstract}

Keywords War of Malvinas - Jornal do Brasil - Soviets - Latin Americans.

\section{Submissão}

IO/O2/2020

$$
\begin{aligned}
& \text { Aprovação } \\
& \text { 20/04/2020 }
\end{aligned}
$$

\section{Publicação}

$29 / 04 / 2020$ 


\section{Introdução}

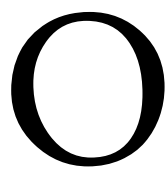

$s$ jornais apresentam-se hoje como um conjunto de fontes bastante significativo para se constituir o conhecimento histórico, e uma força política muito atuante, sobretudo a partir do século $\mathrm{XX}$, quando essas empresas de comunicação se consolidaram enquanto órgãos de poder.

Os periódicos independentes podem ser considerados verdadeiros atores políticos de natureza coletiva, entendidos, fundamentalmente, como instrumentos de "manipulação de interesses e de intervenção na vida social”, como ressaltam Maria Helena Rolim Capelato e Maria Lígia Coelho Prado ${ }^{2}$. Intervêm, nesse sentido, no governo estabelecido, embora nem sempre tencionem conquistar o poder institucional, assim como nos partidos políticos, grupos de interesse, movimentos sociais e na opinião de seus leitores. $\mathrm{Na}$ contramão dessas práticas, os jornais também sofrem interferências dessas partes, sobretudo quando estas são titulares do poder político.

Desconsiderando a hipótese desses veículos de informação serem simplesmente imparciais ou reprodutores neutros dos acontecimentos políticos e sociais, afirmam-se no sistema político e perante outros componentes desse sistema enquanto comentadores e narradores de conflitos entre os mais variados sujeitos; além disso, como afirma Héctor Borrat, os jornais se apresentam como participantes, protagonistas ou não, desses conflitos. Assim, compartilham com os demais sujeitos a necessidade de deliberar e executar estratégias, mobilizando seus recursos para a concretização dos seus objetivos permanentes de lucrar e dissuadir. ${ }^{3}$

Nesse sentido, tomando como fonte um jornal da grande imprensa brasileira, $o$ Jornal do Brasil, objetivamos analisar os debates políticos elaborados pelo periódico a respeito do posicionamento dos demais países latino-americanos diante do conflito, assim como a respeito da possibilidade de interferência soviética em benefício dos argentinos, levando em consideração que o periódico se caracterizava por um posicionamento liberal.

Nelson Werneck Sodré afirma que "O Jornal do Brasil chegava para enfileirar-se entre os grandes”, vinha para durar. Apresentava-se, ao lado de jornais cariocas já consolidados, como o Jornal do Comércio, como uma grande empresa e tomava sempre a vanguarda de inovações da imprensa nacional. O jornal foi fundado em I89I, fruto do

2 CAPELATO, Maria Helena Rolim; PRADO, Maria Lígia Coelho. O Bravo Matutino. Imprensa e ideologia: o jornal O Estado de S. Paulo. São Paulo: Alfa-Omega, ı98o, p. 19.

3 BORRAT, Héctor. El periodico: actor político. Barcelona: Gustavo Gilli, 1989, pp. I4-I5.

$238 \cdot$ ano XI, n. 16, $2020 \cdot \mathrm{ISSN} 2179-5487$ 
desencantamento com o regime republicano, e seus idealizadores, os monarquistas Joaquim Nabuco e Rodolfo Dantas, traçaram as diretrizes básicas da conduta política do jornal enquanto órgão crítico ao governo Deodoro. ${ }^{4}$

No seu auge, o Jornal do Brasil apoiou incondicionalmente o golpe de 1964 e defendeu cassações de políticos, alegando se tratar de uma resposta à radicalização da crise vivida no país. O golpe - ou revolução, conforme a interpretação reacionária endossada pelo periódico - aconteceu, para o jornal, para que se pudesse normalizar a situação interna e permitir que os brasileiros trabalhassem e produzissem como povos organizados. Eduardo Chammas afirma que o Jornal do Brasil advogava, naquele momento, um liberalismo mais pragmático, defendendo inexoravelmente a modernização capitalista sem manifestar preocupação com os direitos sociais. O periódico continuou apoiando incondicionalmente a ditadura, muitas vezes se apresentando como uma extensão do discurso dos militares até 1968, quando foi decretado o quinto Ato Institucional, e começou a sofrer reveses por suas críticas desapontadas ao governo de Costa e Silvas. Na década de 1970, o Jornal do Brasil alinhou-se à conduta de outros grandes jornais, procurando driblar a censura e apresentar mais detalhadamente as notícias, sempre com grande atuação política.

A partir dos anos 1980, como ressalta Bethania Mariani, com a abertura política e o retorno do pluripartidarismo, o processo discursivo que contribuiu para a recriminação do comunismo passou por uma alteração muito simbólica. Com a irrupção das greves e o retorno dos exilados, a denominação "esquerda” começou a ganhar cada vez mais notoriedade nas páginas dos jornais brasileiros, assim, aos poucos a ênfase no comunismo como único inimigo interno cedeu espaço aos novos partidos de esquerda, sobretudo o Partido dos Trabalhadores, moldando um novo inimigo para os "novos tempos"

Os debates que se sucederam no Jornal do Brasil a respeito da Guerra das Malvinas não dialogavam ou se interligavam, a princípio, com a confiança na estabilidade do "mundo ocidental" e nos efeitos mais amplos dos valores liberais, da democracia liberal à economia de mercado. Os prognósticos hegemônicos a respeito do liberalismo enquanto única opção viável para as sociedades contemporâneas estavam abalados àquela altura, como poderemos perceber nas análises empreendidas pelo periódico, pela

4 SODRÉ, N. W. História da Imprensa no Brasil. Rio de Janeiro: Mauad, 1999, pp. 257-258.

5 CHAMMAS, E. Z. A ditadura militar e a grande imprensa: os editoriais do Jornal do Brasil e do Correio da Manhã entre 1964 e 1968. Dissertação (Mestrado) - Faculdade de Filosofia, Letras e Ciências Humanas, Universidade de São Paulo, 20ı2, p. 54.

6 MARIANI, B. O PCB e a imprensa: os comunistas no imaginário dos jornais (1922-1989). Rio de Janeiro: Revan, 1998, p. 218 . 


\section{REVISTA ANGELUS NOVUS}

presença de algumas experiências contestatórias - que conseguiram, em maior ou menor escala, implementar um novo modelo de sociedade, tendo a União Soviética como grande berço, mas também experiências americanas, tão próximas do Brasil - que ameaçavam a supremacia do mundo ocidental. $O$ desenrolar da guerra, a intransigência argentina e o medo constante de uma intervenção soviética no conflito aumentaram os receios do jornal a respeito da estabilidade do continente, levando o Jornal do Brasil a atualizar os argumentos do comunismo enquanto inimigo externo a ser rechaçado.

\section{A guerra de 1982 e a causa Malvinas na cultura política argentina}

Desde março de 1976, vigorava na Argentina a ditadura autodenominada Proceso de Reorganización Nacional. O golpe militar depôs o governo constitucional de María Estela Martínez de Perón, que se via há meses diante de uma insolúvel crise institucional, exacerbada pela crítica situação econômica e pela crescente violência política que se originava de grupos diversos, como da esquerda socialista e comunista, também de tendências de esquerda no peronismo e de paramilitares direitistas aliados ao governo de Isabel Perón. Os militares que assaltaram o poder elencaram os objetivos de reorganizar as instituições, recompor a ordem e planejar uma "verdadeira" democracia. Anunciaram, nesse sentido, um projeto refundador muito mais reacionário que qualquer tentativa predecessora de forçar uma ordem, impondo uma vigilância ferrenha e uma disciplina permanente a todos os grupos políticos e sociais. ${ }^{7}$

Terceiro militar a ocupar a presidência durante a ditadura do Proceso, Leopoldo Fortunato Galtieri, em seu discurso de posse, no dia 22 de dezembro de 198I, prometeu reconquistar a soberania das Ilhas Malvinas, ocupadas pelos britânicos desde i833, recuperando com isso, a honra nacional argentina. Assim, no dia 2 de abril de 1982, as Forças Armadas argentinas invadiram e ocuparam as ilhas, cessando, temporariamente, quase um século e meio de domínio britânico.

A ocorrência da Guerra das Malvinas insere-se no universo de reivindicações do nacionalismo de fins do século $\mathrm{XX}$, e, naquele contexto, conforme aponta Eric Hobsbawm, "o apelo por uma comunidade imaginária da nação parece ter vencido todos os desafios, sobretudo naqueles locais onde as ideologias estão em conflito"; completa afirmando a existência de uma "solidariedade que emana de um 'nós' imaginário, em oposição a um 'eles' simbólico" ${ }^{8}$. E de fato, se nos ativermos às

7 NOVARO, M; P, Vicente. A Ditadura Militar Argentina 1976-1983: do golpe de Estado à restauração democrática. São Paulo: EDUSP, 2007, p. 50.

8 HOBSBAWM, E. Naçôes e Nacionalismo desde 1780. Rio de Janeiro: Paz e Terra, 199I, p. 195.

$240 \cdot$ ano XI, n. 16, 2020 • ISSN 2179-5487 
evidências desse caso, a percepção razoavelmente consensual de uma ideia de nação na Argentina ressurgiu num momento de crise exacerbada de todas as suas instituições, ao passo que antes e após o conflito estruturou-se uma sociedade fragmentada. É certo que não se explica a ocorrência da guerra somente pelo ressurgimento e propagação do nacionalismo, mas foi um fator imprescindível para se criar um universo de cognoscibilidade comum a uma grande parcela daquela sociedade. Mesmo os “dissidentes”, aqueles que não se sentiam representados pelo governo autoritário e pela condução da guerra pela Junta, trataram de ressignificar ${ }^{9}$ a necessidade e a legitimidade da guerra, não perante o Proceso, mas perante a nação. ${ }^{10}$

$\mathrm{O}$ nacionalismo argentino tem a particularidade de ser excessivamente territorialista. O caráter sagrado do solo começou a ser difundido ainda na segunda metade do século XIX, quando as elites liberais argentinas estabeleceram como lugarcomum a crença de que os espólios territoriais - o Alto Peru, o Uruguai e Paraguai -, que impediram a reconstituição do "grandioso" Vice-Reinado do Prata, aconteceram

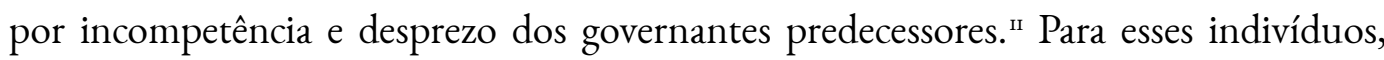
que deveriam governar um contingente enorme de imigrantes com sentimentos localistas muito arraigados, somente a terra poderia fazer com que se identificassem, não sendo fundamentais, portanto, nem a língua, nem a história, nem os acordos de obrigação recíproca. ${ }^{12}$

Nesse sentido, as Ilhas Malvinas tinham - e ainda têm - um excepcional valor simbólico na lógica do relato mítico sobre os desmembramentos e as desapropriações territoriais sofridos pelos argentinos. A questão foi se configurando aos poucos e entre I9I6 e 1943 irrompeu com seus traços mais nítidos. Embora tenha se estabelecido como

Dentro desse nacionalismo cultural, a ideia de usurpação agregava ao território das Malvinas uma eficácia mobilizadora sem precedentes, assim, tratava-se de uma causa nacional em relação à qual, mesmo que a diferença não tenha deixado de se expressar, cada parcela da sociedade deveria se justificar, se nacionalizar. Novaro e Palermo escrevem que "cidadãos comuns que, por uma razão ou outra, consideravam que não se justificava nem a tomada das ilhas, nem o recrutamento de conscritos para defendê-las, sentiram que teriam corrido perigo se o tivessem declarado publicamente”. NOVARO; PALERMO, op. cit., p. 580.

Io LORENZ, F. G. "Testigos de la derrota. Malvinas: los soldados y la guerra durante la transición democrática argentina, I982-1987". In: PÉROTIN-DUMON, Anne (org.). Historizar el pasado vivo en América Latina. [S.1]: [s.n], 2007, pp. 3-63.

II Vicente Palermo explica que o território, enquanto elemento primordial de identificação, foi elevado a tal preeminência não por seu valor enquanto lugar geográfico ou enquanto recurso; antes, as elites liberais trabalharam para inculcar a ideia de que se tratava de algo mais importante: o espírito nacional. O solo era explicado como uma "essência” superior às pessoas, todas mortais, também a todas as instituições, posto que são consideradas historicamente mutáveis, como os Estados, a Igreja, os exércitos. Esta lógica também não eximia os costumes, mesmo os considerados mais virtuosos, uma vez que se alteram com as populações. Nesse sentido, conclui o autor que o solo era a única dimensão resistente às alterações, considerado, pois, imprescindível para alcançar uma identidade coletiva que tendesse a perdurar. PALERMO, V. Sal en las beridas: las Malvinas en la cultura argentina contemporánea. Buenos Aires: Sudamericana, 2007, p. 58. 


\section{REVISTA ANGELUS NOVUS}

um discurso nacionalista muito heterogêneo, reunindo diversos setores da sociedade, foi capaz de congregar os principais traços constitutivos do nacionalismo argentino: o territorialismo, o vitimismo, o unamismo, o decadentismo e o regeracionismo. ${ }^{13} \mathrm{~A}$ partir da década de 1940, noções fundamentais sobre as Malvinas se disseminaram através dos currículos escolares, tornando-se parte do senso comum; contudo, até I955, era um tema pouco discutido e ainda não era a principal pauta de política externa, sendo incorporada somente na década de 1960, quando atribuiu-se uma relevância maior à causa, impulsionada, sobretudo, pela militância nacionalista e peronista.

A ditadura procesista (1976-1983) foi marcada, entre outros aspectos, pela exacerbação dos conflitos territoriais. Como afirma Palermo, os militares se engajaram em um ativismo territorialista tão agressivo que beirava a paranoia. Por muito pouco a Argentina não entrou em guerra com o Chile, em 1978, impulsionada pela feroz competição dentro do próprio regime; ${ }^{14}$ sendo a guerra pelas Malvinas a única empreendida pelas Forças Armadas Argentinas tal como foi concebida no século XX. ${ }^{\text {is }}$ Os militares linhas-duras do Exército, bem como da Marinha, puderam se unificar pela última vez, ainda que de forma muito medíocre, em prol de um objetivo quase fundante do regime, o de usar armas com propósitos territoriais, pressionados pela própria crise do regime e pelo descalabro do plano econômico de Martínez de Hoz.

Àquela altura a questão das Malvinas aproximava-se de uma data bastante simbólica, uma vez que em 1983 completariam I5o anos da ocupação das ilhas pelos britânicos. Nesse quadro, que não permitia a persecução dos objetivos fundantes do Proceso, a ocupação das ilhas, como sugerem Novaro e Palermo, continha motivações sinceras do regime, ao mesmo tempo que oferecia um pacote bastante auspicioso. Unida à demanda territorial nacionalista, a orientação geopolítica da ditadura de transformar a Argentina em uma potência regional cobria o arquipélago, já muito cultivado no imaginário popular, com dotes pretensamente científicos, declarando as ilhas como ricas em recursos naturais e com um território indispensável ao

Vicente Palermo dedica o primeiro capítulo de seu ensaio Sal en las heridas: las Malvinas en la cultura argentina contemporánea (2007) à discussão pormenorizada de todos esses conceitos, considerados "lugares comuns" do nacionalismo argentino. O autor entende o nacionalismo como uma "configuración discursiva propositiva de identidad", assim, explica que se trata de uma configuração porque articula diversos elementos, não sendo, pois, unidimensional, e discursiva porque remete basicamente a um ato de fala. Em síntese, é uma configuração discursiva que compete com outras e interage com crenças de diversos receptores.

I4 A discussão a respeito da estrutura formal adotada pelos militares, após o golpe de 1976, pode ser visualizada no texto de NOVARO; PALERMO, op. cit., pp. 57-67. Os autores sustentam que o próprio modelo implementado conspirou contra a possibilidade de outorgar maior fluidez aos processos de tomada de decisões, uma vez que foram afetados de forma crônica pela falta de coerência e unidade dentro da própria Junta. 
desenvolvimento do Estado Nacional. ${ }^{16}$ Nesse sentido, a ocupação oferecia um bônus duplo aos militares: a mencionada busca pelo desenvolvimento nacional; e a captação, em curto prazo, de um amplo capital político, pois contaria com amplo apoio civil. ${ }^{17}$

Desde 1965, quando se votou a resolução 2065 da ONU - que reconhecia os direitos argentinos sobre as ilhas e convidava as partes à negociação -, a atitude de parcela da burocracia e da diplomacia britânicas foi de verdadeiros acenos no encaminhamento de negociações, contudo, recorrentemente minados pelo próprio Parlamento e pela imprensa. Embora os ingleses reproduzissem um discurso pró-ilhéus, ficava cada vez mais insustentável a retórica de acompanhar a manutenção da defesa e o desenvolvimento econômico das ilhas. Desde 1982, quando se optou por retirar o navio de patrulha HMS Endurance das ilhas, por medidas econômicas, estava mais ou menos claro que a intenção dos britânicos era a de se retirar gradualmente da região. Carecia de fundamento, como bem explicam Novaro e Palermo, a tese segundo a qual os britânicos não cederiam nunca a soberania das ilhas. Havia boas possibilidades àquela altura para frutificarem as negociações em favor da Argentina, não fosse o tempo dos militares estar se esgotando e a arrogância das elites argentinas, para as quais os ilhéus eram mero detalhe a ser superado. ${ }^{18}$

Desde o início de 1982, a diplomacia argentina se tornava cada vez mais agressiva em suas reivindicações, e a situação se tornou insustentável quando um grupo de sucateiros, liderados por um civil, Constantino Davidoff, desembarcou em uma das ilhas do arquipélago. Embora não existam provas conclusivas de que o desembarque tenha sido uma operação militar encoberta, o certo é que um dos integrantes da Junta, Jorge Anaya, contrariando as ordens do chanceler Nicanor Costa Méndez de suspender a operação, prosseguiu na ocupação, enviando um barco de patrulha para defender os

I6 NOVARO; PALERMO, op. cit., p. 54I.

I7 Em 1979, a Argentina via um agravamento histérico de sua crise: as dívidas pública e privada fizeram-se impagáveis após uma alta nas taxas internacionais, aumentando, consequentemente, a recessão e criando uma brusca aceleração inflacionária. Ao passo que Videla apostava tudo no restabelecimento da economia, intentando, dessa forma, desmobilizar dissensos internos e externos, colhia cada vez mais frustrações das medidas implementadas por seu Ministro da Economia, Martínez de Hoz. Seu sucessor, escolhido pela Junta, Roberto Viola, ainda que breve na presidência, implementou medidas tão desastrosas que, em 198I, quando Leopoldo Galtieri o sucedeu na presidência, seu governo ficou assinalado pela pior crise econômica argentina. A propaganda do último governo da ditadura seria marcada, então, pela promessa de que o Proceso retomaria seu vigor e projetos fundantes. NOVARO, M. Historia de la Argentina. 1955-20Io. Buenos Aires: Siglo Veintiuno Editores, 2010, p. I83.

I8 Segundo Novaro e Palermo, não somente para os militares como também para uma grande parcela civil o principal interesse na causa Malvinas era o território. De 1965 a 1982, a Argentina viveu uma instabilidade política aguda, e suas elites não se importavam que não interessava aos ilhéus viver sob uma ditadura ou mesmo sob a soberania argentina. NOVARO; PALERMO, op. cit., p. 545. Nicanor Costa Méndez, o ministro das Relações Exteriores de Galtieri, contribuiu muito para a sustentação da tese segundo a qual a negociação era inexequível e que, portanto, deveriam empregar o poder militar defensivamente, ocupando as ilhas para persuadir a Grã-Bretanha a reconhecer a soberania argentina. 


\section{REVISTA ANGELUS NOVUS}

trabalhadores argentinos. Imediatamente Thatcher ordenou que o HMS Endurance retornasse às ilhas para averiguar o ocorrido; a crise estava instaurada. Demais integrantes da Junta concluíram do ocorrido que não era mais possível se retirarem das ilhas sem maiores consequências políticas ou sem que fossem humilhados perante a população argentina. O entendimento foi, então, que a ocasião proporcionaria uma excelente justificativa para a ocupação definitiva das ilhas. ${ }^{19}$

Típica de um golpe de mão, a invasão das Malvinas deu-se em 2 de abril, a partir de uma ordem expedida pelo presidente Galtieri: rápida e sem feridos. A fase propriamente bélica do conflito deu-se somente no início de maio e, com isso, as características físicas da batalha logo mostraram a preponderância tecnológica e de capacidades profissionais britânicas, mas, acima de tudo, evidenciaram os equívocos irremissíveis do diagnóstico prévio feito por Galtieri e pelos poucos que arquitetaram o conflito na surdina: supunha-se que os britânicos não combateriam; que os norteamericanos apenas assimilariam a política do fato consumado; e que o restante dos comandos argentinos, que desconheciam o planejamento do golpe de mão, apoiá-losiam por falta de escolha. Como ressaltam Novaro e Palermo, ${ }^{20}$ apenas a última avaliação se concretizou. Vejamos o que sucedeu em cada caso.

Havia a correta percepção dos militares argentinos de que a Inglaterra estava mergulhada em problemas graves, como seu declínio imperial e sua perda de capital político no cenário internacional; contudo, erraram ao não perceber que a PrimeiraMinistra, Margareth Thatcher, assim como eles, usaria a ocupação das ilhas para tentar resolver esses problemas. ${ }^{21}$ Vicente Palermo sustenta que a crise criou para os britânicos uma autêntica Falkland's cause, que se manifesta em duas faces: a primeira, a campanha militar forjou um forte apelo de reconstrução da confiança nacional, sendo que muitas vezes a guerra pelo arquipélago é comparada aos tempos da Segunda Guerra Mundial, quando um período de políticas vacilantes foi contornado pela expertise de um grande líder; a segunda, fortemente relacionada aos valores de liberdade declarados pelos

I9 NOVARO; PALERMO, op. cit., p. 555 .

$20 \quad$ Ibidem, p. 560.

2I O Governo Thatcher caracterizava-se por uma forma de neoliberalismo particularmente autoritária, pois o Estado fortaleceu-se em algumas áreas enquanto perdia poder em outras. Num radical processo de centralização, as autoridades locais perderam autonomia frente ao poder da Primeira-Ministra, tornando o governo central mais poderoso nas áreas de habitação e educação; diminuindo, também, a autonomia dos conselhos locais de elevar impostos e aumentando, de uma forma sem precedentes, o poder da polícia política com a aprovação da Lei de Segredos. Além disso, o alto índice de desemprego elevou as despesas com a Previdência, ao mesmo tempo que as despesas com habitação decresceram, aumentando o índice de moradores de rua. A agressiva política antissindicalista de Thatcher alterou radicalmente o poder de barganha dos sindicatos, fazendo com que a renda proveniente do trabalho caísse para $73 \%$ da renda familiar bruta em 1982. Em síntese, a popularidade da Primeira-Ministra ia muito mal. MAZOWER, M. "A crise do contrato social”. In: MAZOWER, Mark. Continente Sombrio: A Europa no século XX. São Paulo: Companhia das Letras, 200o, pp. 32I-353. 
britânicos e ao orgulho de terem destruído os ditadores argentinos para finalmente valorizarem as ilhas, até aquele momento negligenciadas ${ }^{22}$. Disso tudo, o mais correto é que Thatcher definiu a forma como a Grã-Bretanha enfrentou o conflito e foi habilidosa o suficiente para remover todos os empecilhos, internos e externos.

Tanto para a Grã-Bretanha quanto para os Estados Unidos, a agressão argentina violava o pacto de estabilidade internacional do qual ambas as potências se consideravam guardiãs, especialmente a segunda. Embora desagradasse a Reagan a possibilidade de ter de escolher entre a Argentina, um país que colaborava indiscriminadamente com a sua política para a América Central, e a Grã-Bretanha, tradicional aliado e membro da OTAN, pesava mais a manutenção da aliança com a Grã-Bretanha, sobretudo pelo recrudescimento da Guerra Fria na agenda externa do presidente republicano. O governo norte-americano designou, nesse sentido, o Secretário de Estado, Alexander Haig, para uma missão de alto nível, em que sua posição, para além de um mediador neutro, foi a de intervir diretamente no conflito, na intenção de minar as possibilidades de um confronto bélico. ${ }^{23}$ Ainda que os Estados Unidos tivessem trabalhado intensamente na mediação, a intransigência da Junta e da Primeira-Ministra, comprometida inarredavelmente com a exigência de que as tropas argentinas se retirassem imediatamente e com a retórica de defesa dos ilhéus, fez com que um conjunto de negociações fracassassem. Assim, no dia 30 de abril, um dia após o governo argentino ter rejeitado a última proposta, o Senado dos Estados Unidos aprovou uma resolução exigindo a retirada imediata das tropas argentinas, estabelecendo uma série de embargos e oferecendo o apoio material às tropas britânicas.

Já a atuação da diplomacia brasileira foi restringida, em parte, pela deterioração das condições do cenário internacional. ${ }^{24}$ Contudo, havia o esforço sincero de manter as boas relações com a Argentina, inauguradas com a resolução do impasse Itaipu-Corpus, em 1979. Nesse sentido, o Brasil posicionou-se pela neutralidade, de caráter imperfeito, visando manter suas relações estáveis, também, com o governo conservador de

22 PALERMO, op. cit., pp. 31-32.

23 NOVARO; PALERMO, op. cit., p. 586.

24 Das exportações dependia a vinda de insumos físicos, tecnológicos e financeiros, mas essa percepção do governo esbarrava em um protecionismo impermeável dos grandes centros de poder, em um diálogo NorteSul minguado há anos e na manutenção de regras desfavoráveis no comércio internacional. Como ressaltam Francisco Luna e Herbert Klein, a crise do mercado internacional de 1979 reduziu drasticamente a oferta de capitais para países devedores, impossibilitando a renovação dos empréstimos externos. As taxas internacionais de juros, que somente em 1979 ultrapassaram os Io\%, continuaram a se elevar durante os anos seguintes. Assim, o descalabro das contas públicas internas, somado ao choque dos preços provocado pela alta no valor do petróleo, levaram a um aumento vertiginoso da inflação e a um grande endividamento externo e interno. LUNA, F. V.; KLEIN, H. "Transformações econômicas no período militar (1964-1985)”. In: FILHO, Daniel Aarão Reis; RIDENTI, Marcelo; MOTTA, Rodrigo Patto Sá (orgs.). A ditadura que mudou o Brasil: 50 anos do golpe de 1964. Rio de Janeiro: Zahar, 2014. pp. 92-III. 


\section{REVISTA ANGELUS NOVUS}

Margareth Thatcher, sobretudo porque o Brasil dependia grandemente de capitais londrinos. Assim como os Estados Unidos, o Brasil procurou cumprir um papel de mediador, seja no âmbito bilateral, seja no âmbito multilateral (na Organização dos Estados Americanos e, principalmente, na Organização das Nações Unidas), e durante todo o conflito manteve sua posição de apoio à reivindicação argentina pelas Malvinas ao mesmo tempo que condenava o uso de recursos bélicos.

A neutralidade imperfeita adotada pelo Brasil pendia em favor dos argentinos, auxiliando-os diplomaticamente e economicamente. Como explica Marcelo Walsh, o entendimento jurídico da Chancelaria brasileira, desde I833, foi o de que "nunca houve um laudo arbitral ou sentença internacional ou tratado que dessem validade jurídica erga omnes à ocupação das Ilhas Malvinas pelo Reino Unido". ${ }^{25}$ Destarte, desde 1965, quando a questão foi para o Comitê de Descolonização das Nações Unidas, o Brasil votou favoravelmente às principais resoluções (1965, 1973 e 1976). Durante o conflito, o governo brasileiro assumiu a representação dos interesses argentinos na Grã-Bretanha, por meio da sua Embaixada em Londres, e permitiu o escoamento de parte de sua produção agropecuária pelos portos de Santos, Paranaguá e Rio Grande, visando atenuar o impacto dos embargos impostos pela Comunidade Econômica Europeia (CEE) e pelos Estados Unidos. ${ }^{26}$

Por fim, mencionemos os comandos argentinos durante a guerra. No decorrer das semanas de abril, o arquipélago foi incrivelmente preenchido por mais de 12 mil soldados, entre os quais, mais de $50 \%$ eram recrutas, jovens entre 18 e 20 anos. Muitos desses indivíduos já haviam concluído o serviço militar obrigatório, outros apenas receberam um treinamento básico de três meses. Federico Lorenz afirma que os argentinos acompanharam as notícias da guerra a partir do estado de censura que vigorava na Argentina, e a crença e a esperança nos jovens soldados foi impulsionada ao máximo pela possibilidade de se regenerar a história nacional. Tratava-se da última oportunidade de "serem melhores, de serem mais unidos, de terem um objetivo comum e de pensar em um país sério". ${ }^{27}$ Ao longo do conflito não houve, segundo Novaro e Palermo, nada que se assemelhasse a um comando militar unificado, e a própria estrutura do regime se projetou no teatro de operaçôes: embora colhessem o fruto do mal diagnóstico e da forma brusca com que invadiram as ilhas, bem como da falta de perspicácia analítica e de capital organizacional, a autonomia das forças e a desunião na

\footnotetext{
25 WALSH, M. V. A Atuação do Brasil frente à Crise das Malvinas/Falklands (1982). Dissertação (Mestrado) Instituto de Ciências Humanas, Universidade de Brasília, Brasília, 1997, p. Ioo.

26 Ibidem, p. 47

27 LORENZ, op. cit., p. I2.
} 
tomada de decisões ecoaram diretamente na ação militar. ${ }^{28} \mathrm{~A}$ derrota desferiu o golpe final na crise que se arrastava no governo: o Exército teve mais de 1200 entre mortos e feridos, cerca de io mil retornaram enquanto prisioneiros.

\section{A “outra” América e os comunistas no conflito}

Em diversos momentos as diferenças entre brasileiros e hispano-americanos foram destacadas com a finalidade de apresentar o Brasil como o lugar da "ordem" e da "unidade" em oposição à "fragmentação" e à "anarquia" dos países hispanoamericanos. Katia Baggio $^{29}$ afirma que os intelectuais brasileiros das primeiras décadas republicanas, divididos em duas tendências, escreveram, sobretudo em jornais e revistas, com a finalidade de explicar o seu tempo e propor projetos para o "futuro da nação". A primeira tendência interpretativa valorizava a tradição ibérica, sobretudo o período imperial, que era entendido como a época da estabilidade, do progresso e da unidade territorial. A segunda linha interpretativa valorizava o modelo republicano liberaldemocrático dos Estados Unidos como forma de superar o atraso e construir uma nação moderna e civilizada, ao mesmo tempo que rejeitava o legado português relacionado aos períodos colonial e imperial. ${ }^{30}$ Vejamos, nesse sentido, como o Jornal do Brasil soube se aproveitar das duas tendências, congregando-as:

A crise das Falklands é, em parte, reflexo do clima político argentino - clima que ajuda a explicar a impetuosidade sem raízes, o desejo de retirar do horizonte, ao menos por um momento, problemas crônicos; de forjar, ainda que artificialmente, uma sempre distante unidade nacional.

Mas os fatores que levaram à crise de agora não são só de hoje - nem apenas argentinos. Assiste-se, como que por mágica, ao reaparecimento do herói caudilho, do "homem forte" que pretende tomar o destino (ou as Falklands na mão).

A veia caudilhesca é como um rio subterrâneo que emerge, eventualmente, nesta parte do continente. Analisou-a há mais de um século um grande argentino - Domingo Faustino Sarmiento - em um livro (o Facundo) que pode ter sido uma das fontes de inspiração de Os Sertóes) (e que como os Sertôes foi publicado inicialmente em folhetins de jornal. No Facundo como nos Sertôes, vê-se o homem americano colocado diante da imensidão da terra: o que pode

28 NOVARO; PALERMO, op. cit., p. 597.

29 BAgGiO, K. G. A "Outra" América: a América Latina na visão dos intelectuais brasileiros das primeiras décadas republicanas. 1998. 226 f. Tese (Doutorado) - Faculdade de Filosofia, Letras e Ciências Humanas, Universidade de São Paulo, São Paulo, 1998, pp. 24-25.

30 Após analisar diversos autores, Baggio concluiu que, embora houvesse diferenças entre cada um, prevaleceram representações negativas da América Hispânica. Assim, foi recorrente a formulação de representações como barbárie, caudilhismo, desordem, caos social, ditadura, violência política, anarquia, autoritarismo, fragmentação, federalismo degenerado, entre outras, acerca desses países. Ibidem, p. 209. 


\section{REVISTA ANGELUS NOVUS}

esmagá-lo, mas também pode dar origem ao homem que cria a sua própria lei. Essa autocriação tanto tem um lado épico como pode produzir o perfeito tirano. Condenado à morte por Rosas, Sarmiento conheceu o pior aspecto do caudilhismo e sonhou com uma Argentina que se evoluísse no sentido institucional.

O caudilhismo não é apenas argentino. Os pampas não fazem distinção de fronteira; e o Brasil tanto produziu, em Getúlio Vargas, a sublimação do caudilho como teve caudilhos ortodoxos - bastando citar, nesse sentido, um Borges de Medeiros.

Na tradiçáa brasileira, entretanto, esse lado caudilhesco - já de si menos virulento que no mundo hispânico - foi temperado por um impulso constitucionalista que quase participa da natureza do milagre. Ninguém ignora que D. Pedro II foi anticaudilho por excelência; mas o que é menos lembrado é que o primeiro Pedro também sentiu com grande força a sedução do constitucionalismo, através de influência como dos irmãos Andrada (José Bonifácio e Antonio Carlos) ou por convicção própria. Mesmo quando fechou a Assembléia, na crise política de I824, o Imperador compensou este ato outorgando a sua própria Constituição; e esta Constituição não apenas durou até I891, servindo a todo o Segundo Império, como era suficiente flexível para trazer em seu bojo a possibilidade parlamentarista que o Segundo Pedro poria em prática e aperfeiçoaria. Abandonado o Brasil, Pedro I foi defender, em Portugal, a mesma mística constitucionalista, contra o absolutismo dos miguelistas.

Esta a tradição brasileira, que não se deveria perder de vista quando se quiser retornar o fim das nossas origens para fazer uma "democracia à brasileira". ${ }^{3}$

Para o jornal, a crise que se instaurou na Argentina tinha raízes profundas e o periódico considerava o caudilhismo um velho fenômeno conhecido da região. Naquele momento, o reaparecimento do caudilho tinha como missão, segundo o Jornal do Brasil, a tomada das "Falklands nas mãos". Embora reconhecesse que o caudilhismo não fazia menção somente à Argentina, para o jornal, na tradição brasileira esse "lado caudilhesco" era menos virulento do que no "mundo hispânico", posto que tivemos um imperador convicto e afeito ao constitucionalismo e outro imperador anticaudilho por natureza. Nesta lógica, os dois imperadores impulsionaram o Brasil ao "milagre do constitucionalismo", diferentemente das desafortunadas repúblicas vizinhas. As distinções criadas nas primeiras décadas do século XX se mantiveram ao longo do período republicano, mas as duas tradições mencionadas acima foram diluídas na análise que o Jornal do Brasil fez da crise envolvendo os argentinos. Não restam dúvidas de que, para o periódico, o modelo republicano liberal-democrático de inspiração norte-americana era o único viável; contudo, a publicação não deixava de valorizar o período monárquico como responsável por estabelecer as bases do Brasil potência. Como o Brasil também havia aderido, posteriormente, ao modelo republicano, não havia outra forma de explicar o caótico mundo hispânico senão retomando o período imperial brasileiro, o principal diferencial. 
No dia 12 de abril, quando a Argentina apresentou a proposta de retirar suas tropas das ilhas mediante a paralisação da frota britânica que rumava ao Atlântico Sul, o Jornal do Brasil lançou um editorial que acenava para o medo da intervenção soviética no conflito e representava - dentro dos parâmetros mencionados acima - o Peru como um país que agia de maneira sub-reptícia:

Em compensação, já se pode discernir os redemoinhos maléficos provocados por esta crise. Fatos estranhos estão acontecendo, como a entrada ilegal de um avião cubano no espaço aéreo brasileiro, ou a notícia de que um pequeno navio soviético vem seguindo o transatlântico utilizado por Londres para o transporte de tropas. A Argentina já teria trocado de hemisfério?

Pior é saber que o Peru dispõe-se a apoiar a "causa argentina" contra o "neocolonialismo". Num momento tão grave, só haveria uma causa a ser apoiada, a da paz. Mas assim como há quem se aproveite de incêndios e terremotos para realizar pequenos ou grandes furtos, como não imaginar que o Peru aproveita a situação para angariar um futuro apoio argentino em reivindicações que tem a apresentar (como os argentinos) ao Chile?

Eis ao que já está levando este conflito absurdo, em que as acusações de "neocolonialismo" à Inglaterra são um biombo como qualquer outro. Já não cansa a agência Tass de bater nesta tecla? Teremos então a União Soviética como campeã dos interesses sul-americanos frente aos monstros europeus? 32

Esse medo anticomunista foi ainda mais radicalizado em um artigo escrito por Noênio Spíndola, no qual mapeou o aumento das relações econômicas entre a União Soviética e a Argentina. O articulista construiu perfeitamente o "fantasma do comunismo", escandalizando-se diante de dados que, a princípio, ele mesmo considerava frívolos. Esse comércio, como bem explicou Spíndola, foi fruto do embargo estadunidense às exportações soviéticas de cereais, como forma de puni-los por terem invadido o Afeganistão. Concluiu a esse respeito que Jimmy Carter fê-lo "sem medir as consequências para o movediço terreno do comércio mundial” (Jornal do Brasil, o8/o5/1982, p. II). Mais adiante, o articulista escreveu o seguinte:

Do ponto-de-vista de Moscou, todas essas iniciativas foram descritas como simples consequências da vontade dos Estados soberanos diversificarem suas relações comerciais. Do ponto-de-vista ocidental, a aproximação Buenos Aires-Moscou não apenas representava um torpedeamento do embargo às vendas de cereais proposto por Washington, mas ainda uma possível brecha para os soviéticos no Atlântico Sul.

(...) Frios e calculistas, os representantes do alto Staff do Ministério do Comércio Exterior da URSS continuaram a participar das opulentas recepções da Embaixada argentina em Moscou, comendo seus fartos churrascos e confraternização em meio a padres ortodoxos, diplomatas e invejosos representantes de outras delegaçôes comerciais. 


\section{REVISTA ANGELUS NOVUS}

Aos poucos, os laços foram se estreitando: uma troca de adidos militares foi feita pela Embaixada argentina com grande farra diplomática.

Com a URSS como maior parceiro comercial da Argentina, a crise das Falklands estourou. Esta é agora um vasto terreno para hipóteses, mas é difícil acreditar que Buenos Aires não tomará a lição das últimas semanas como um empurrão adicional na direção de Moscou. $\mathrm{O}$ que os soviéticos podem oferecer é uma variada coleção de alternativas já utilizadas para colocar outros países gravitando em sua esfera de influência. ${ }^{33}$

O comércio soviético-argentino foi considerado uma afronta às regras estabelecidas pelo guardião do livre mundo ocidental e uma clara demonstração do encaminhamento sorrateiro da União Soviética ao Atlântico Sul. Pior, tacitamente consentidas pelos argentinos. No editorial do dia I2 de abril, o Jornal do Brasil se perguntava se a "Argentina já teria trocado de hemisfério?” por conta de um "pequeno navio soviético" que cruzava o transatlântico. Conforme ressalta Rodrigo Patto Sá Motta, o argumento anticomunista possui caráter multifacetado, uma mistura entre manipulação e convicção que se ajusta e converge diferentemente em circunstâncias diversas, resultando em uma força - e que propõe uma ação - política bastante poderosa. Contudo, uma regularidade não deixa de ser percebida na reprodução de mitos, imagens, ideias e outras representações construídas entre as décadas de 1920 e 1930 e ainda utilizadas na década de 1980. ${ }^{34}$ A profundidade do anticomunismo de Spíndola, para além de atacar enfaticamente a "depravação" moral dos soviéticos, permitiu a ele afirmar que "a crise das Falklands" só estourou com o crescimento do comércio entre argentinos e soviéticos, embora fizesse mais de um mês a invasão das ilhas.

$\mathrm{O}$ anticomunismo originou, pois, um imaginário próprio, a fim de convencer a sociedade da necessidade de negar e de combater o comunismo. Ainda segundo Motta, essencialmente, o comunismo foi associado à figuração do mal, "tal qual as sociedades humanas normalmente entendem e significam o fenômeno", ligando-o aos prognósticos de pecado, sofrimento e morte, assim como foi reforçada a imagem de que a prática dos comunistas levaria à fome, à miséria, à tortura e à escravização. 35 Os argumentos anticomunistas não provinham apenas de católicos, nacionalistas ou liberais, de forma dissociada; muitas vezes havia uma combinação das três dimensões, guardadas, também, as suas especificidades. Outro aspecto do anticomunismo que nos interessa é o pressuposto de que os planos e as ações dos comunistas chocavam-se com a moral orientadora das sociedades "cristãs" e "ocidentais", uma vez que intentavam

33 SPÍNDOLA, N. Artigo: "O eixo econômico Moscou-Buenos Aires", Jornal do Brasil, o8/o5/1982, p. II, grifos nossos.

34 MOTTA, R P. S. Em guarda contra o perigo vermelho: o anticomunismo no Brasil (1917-1964). São Paulo: Perspectiva/Fapesp, 2002, pp. IO-I2.

35

Ibidem, p. 72.

$250 \bullet$ ano XI, n. 16, 2020 • ISSN 2179-5487 
destruí-la. Assim, o comunismo representava um desafio à manutenção da própria sociedade civilizada, ameaçada pelo retorno à barbárie. ${ }^{36}$

É difícil distinguir a dose de crença da manipulação pretendida pelo articulista - o mais correto, acreditamos, é a coexistência de ambas -, ainda mais quando ele próprio assume incongruências em seus argumentos. Contudo, o medo da intervenção soviética no continente era sincero, reforçado em diversos artigos e editoriais. Mobilizando amplamente seu quadro redacional, o jornal trabalhou incessantemente na pauta da crise anglo-argentina, aconselhando e criticando. Convergiu, inexoravelmente, na defesa dos interesses do jornal e de seus projetos para o país. O jornal há muito tempo vinha opinando pela reinserção do Brasil no "concerto de nações”, e a crise era entendida como um fator de atraso para efetivação desse projeto. Ademais, outro medo bastante reforçado pode ser visto em mais um trecho da coluna de Castello Branco:

A última esperança dos grupos radicais de impedir as realizações da eleição de novembro situa-se nas Ilhas Malvinas. Se houver, como desfecho de luta, uma erosão do Governo argentino e uma ascensão da esquerda, as Forças Armadas poderiam ser induzidas a adotar a providência cautelar de evitar uma eleição popular no Brasil. ${ }^{37}$

Raras vezes o periódico escreveu sobre os impactos mais profundos que a guerra causaria à população argentina, associando, dessa forma, a crise aos interesses mais próximos do Brasil. Um editorial do dia is de abril explicou melhor a visão do jornal a respeito do lugar do Brasil no conflito:

Em meio a tantos impasses, é impossível deixar de perceber o flanco descomunal que se abre, neste continente, às interferências externas. Deixando de atender à reconsideração expressa do Conselho de Segurança da ONU, no sentido de que retirasse as tropas de ocupação para que verdadeiras negociações pudessem ter início, a Argentina expõe-se a uma vigorosa pressão da Comunidade Econômica Européia. Tão ou mais exposto encontra-se agora o Atlântico Sul à navegação desembaraçada de uma superpotência que não tinha bases naturais nem qualquer afinidade especial com este continente. Isto não deveria ter bastado para que a Argentina considerasse melhor a forma de reivindicar seus eventuais direitos?

A gravidade da crise, entretanto, não comove a grande maioria dos países sul americanos: parece, essa imensa maioria, ansiosa para fazer valer um simples direito de opinião; ou uma solidariedade continental que, neste caso, é totalmente descabida - pois estamos diante de uma aventura militar.

Interesses concretos podem ser entrevistos, às vezes, em meio a tanta desenvoltura. Depois do ardoroso apoio concedido pelo Peru e pela Bolívia à Argentina (futuros aliados contra o 


\section{REVISTA ANGELUS NOVUS}

Chile?), também a Venezuela alinha-se irresistivelmente com Buenos Aires; porta aberta para uma solução enérgica da sua própria questão com o Suriname?

O alinhamento com Buenos Aires ganha tanto espaço, com efeito, que não se pode deixar de lado o aspecto instintivo, impulsivo, da questão; o ressentimento de pequenos contra grandes, o desejo de desforra em relação a um antigo poder imperial.

(...)

É neste cenário aparentemente ensandecido que o Brasil não pode deixar preservar a sua própria posição. O Brasil fundou toda a sua tradição diplomática na negociação. O Brasil teve e tem interesses próprios, e a linha sutil traçada pelas fronteiras lingüisticas encarregou-se de criar, também, certas diferenças de comportamento e temperamento.

Ao mesmo tempo, o Governo brasileiro e outros intérpretes da nacionalidade não se privam, quando há ocasiões para isso, de sublinhar a condição de potência emergente em que já não é impróprio situar o Brasil. Uma potência de hoje ou de amanhã tem compromisso com seu destino; precisa enxergar um pouco além dos horizontes regionais, um pouco além do boje e do amanhã. O Brasil não tem por que deixar-se arrastar para a "prova de força” que parece seduzir alguns de seus vizinhos. Fica-lhe bem o sangue-frio até para que possa começar a remediar, desde já, as conseqüências danosas que já estão à vista em várias direções. ${ }^{38}$

Ainda que o jornal estivesse defendendo os seus interesses e, consequentemente, o seu projeto para o Brasil, criticou os vizinhos sul-americanos por fazerem o mesmo. $\mathrm{O}$ próprio nome do editorial, "Fronteiras da Razão", explica muita coisa a respeito da forma como o jornal lia os respectivos interesses. Nesse caso, os interesses do Brasil eram mais racionais, próprios da delimitação das "fronteiras linguísticas” que estabeleceu uma diferença de "comportamento" e de "temperamento" dos seus vizinhos hispânicos. Assim, o Brasil tinha "a" "razão" ao seu lado para defender seus ilustres projetos, enquanto seus vizinhos - essa imensa maioria - tinha apenas o desejo de "fazer valer um simples direito de opinião". O "gigante brasileiro na América Latina" enxergava para "além dos horizontes regionais". ${ }^{9}$ O jornal fazia um apelo à superioridade da razão iluminista, promotora do progresso, sempre positiva,

38 Editorial: "Fronteiras da Razão", Jornal do Brasil, 15/04/1982, p. ıo, grifos nossos.

39 Maria Helena Capelato afirma que desde a década de 1950 o Brasil era estampado na imprensa, em um clima de grande otimismo, como "líder no continente", sobretudo pelos bônus que conseguiu adquirir e usufruir após a Segunda Guerra e pelo sucesso da política desenvolvimentista. A ideologia do "Brasil grande potência" do governo Médici consolidou essa perspectiva. CAPELATO, M. H. R. "O 'gigante brasileiro' na América Latina: ser ou não ser latino-americano”. In: MOTA, Carlos G. (org.). Viagem incompleta. A experiência brasileira (I500-2000): a grande transação. São Paulo: Editora SENAC São Paulo, 200o. pp. 285-316. Fernando Devoto e Boris Fausto escrevem que a euforia, concentrada sobretudo nos setores da classe média, estava condicionada pela perspectiva de que o Brasil ingressaria no seleto clube dos países hegemônicos até o final do século XX. Assim, os anos repressivos - tidos como incômodos, mas inevitáveis - que alocaram o "milagre" econômico foram o exemplo mais nítido da legitimação da ditadura brasileira pelos êxitos econômicos. No que se refere à Argentina, Devoto e Fausto concluem que os militares perderam a batalha para a legitimação do regime autoritário a partir do insucesso da organização econômica. DEVOTO, F; FAUSTO, B. ArgentinaBrasil: 1850-2000. Buenos Aires: Sudamericana, 2000, p. 390. O Jornal do Brasil deixava muito claro seu entendimento sobre a "incompetência" dos militares argentinos para reestabelecer a ordem política, social e econômica. 
desqualificando seus vizinhos hispânicos por serem irracionais e demasiadamente sentimentais.

Ao passo que o Jornal do Brasil representava os argentinos como selvagens, à Primeira-Ministra Margareth Thatcher cabia a imagem de uma estadista forte, patriota, convicta, implacável, contudo, humana. Considerava que suas decisões eram tomadas com moderação e tinha sempre a sabedoria de revidar apenas o necessário. Assim, quando noticiou a recepção dos ingleses, na Câmara dos Comuns, a respeito dos mortos em combate, o Jornal do Brasil escreveu da seguinte forma a parte que concerne à Primeira-Ministra: "A Primeira Ministra Margareth Thatcher, vestida de preto, ouvia em silêncio na primeira fila. Assessores disseram que a notícia a deixou arrasada" ${ }^{\circ}$. Essa oposição entre silêncio e barulho já havia aparecido em uma charge de Ziraldo do dia 28 de abril: nessa ocasião, um argentino foi representado bastante alterado, esbravejando palavras de ordem em uma perfeita confusão: "La patria pra friente o murte! Viva la guerra! Patria nuestra! Viva la muerte!” ${ }^{4}$. Do outro lado, um britânico bastante polido foi representado com uma xícara de chá, respondendo em retidão: “disgusting" [repugnante]. Esse modelo explicativo que desqualifica seus vizinhos hispânicos é muito caro ao Jornal do Brasil, sendo recorrentemente empregado, como veremos mais adiante.

No dia 25 de abril, após o Ministro das Relações Exteriores do Brasil, Ramiro Saraiva Guerreiro, ter feito um discurso criticando a postura dos países de "Primeiro Mundo" por terem reforçado os embargos à Argentina, e ter afirmado que isso afetava sobremaneira os países de "Terceiro Mundo", entre os quais o Brasil estava alocado, o Jornal do Brasil escreveu um editorial para interpretar o conceito de terceiromundismo. Para o jornal, o Brasil não tinha por que ter "complexos políticos, econômicos ou culturais", pois era "um país viável há muito tempo", com uma política externa "exemplar", a "décima economia mundial", "extremamente dinâmico"; entretanto, corria um sério risco:

A crise absurda em torno das Ilhas Falklands colocou de repente o que se poderia chamar de comunidade ocidental ante um desafio tão sério que chega a pôr em risco, nas hipóteses mais sóbrias, a sua própria existência. Seria este, portanto, o momento para que a diplomacia brasileira, que tem sido no máximo habilidosa, definisse melhor os seus objetivos.

Se a Argentina está levando ao auge uma tendência à esquizofrenia cortejando alianças externas que são, no sentido exclusivamente político, o inverso da sua realidade interna, já

$40 \quad$ Jornal do Brasil, 05/05/1982, p. 2.

4I Jornal do Brasil, 28/04/1982, p. Io. 


\section{REVISTA ANGELUS NOVUS}

há suficientes indicações de que o Brasil ouve a música de sereias parecidas, e de que não há muita coerência entre a política externa que praticamos e o cenário nacional.

(...)

Brincando de Terceiro Mundo, jamais assumiremos a verdadeira dimensão do Brasil. Esse "romantismo da pobreza” tem efeitos deletérios até no plano interno: estimula a aparição de salvadores, dos messias; acostuma a sociedade a viver à sombra do Estado protetor. A face externa desse desfibramento geral é uma permanente e ressentida atitude de pedinte adotada pelos representantes mais típicos do terceiromundismo.

Ninguém ignora que há desigualdades estratificadas no plano internacional, que negociaçôes internas e competentes deveriam procurar corrigir. Mas dessas desigualdades têm-se alimentado os Pais da Pátria e os movimentos ditos de "libertação" sempre dispostos a trocar uma dependência por outra, e a fazer o jogo do bloco socialista.

São essas superstições (no sentido etimológico) que o Brasil precisa abandonar urgentemente. Para fazer uma política competente, não precisamos fugir de nossa rota natural, das nossas alianças naturais e tradicionais. Não precisamos ter medo do desenvolvimento. Muito pelo contrário: os contatos que conservamos (e temos de desenvolver) com o “primeiro mundo" são o antídoto indispensável contra o subdesenvolvimento cultural, contra a doença do estatismo.

Este é o horizonte em que se gostaria de ver enquadrada a diplomacia brasileira. E não no "museu de antiguidades" dos que continuam a romantizar a pobreza e o atraso. ${ }^{42}$

Esse editorial marca muito bem a postura incoerente do Jornal do Brasil, o seu apreço pelo liberalismo econômico que enfatizava muito mais a sua luta contra o intervencionismo estatal do que propriamente a questão da participação política. $\mathrm{O}$ Brasil versado em chavões convencionais nesse editorial é uma potência livre que se sobrepunha ao mundo soviético de servidão. Como um pai que amavelmente adverte, o Jornal do Brasil tentava explicar o porquê de a chancelaria estar equivocada ao empregar o termo "terceiromundismo" ao Brasil, posto que o país possuía uma "rota natural” e "alianças naturais e tradicionais" que não escapavam do Ocidente. O medo do jornal era que o discurso de Guerreiro estimulasse "a aparição de salvadores, dos messias" que "acostuma a sociedade a viver à sombra do Estado protetor." O medo maior era que o discurso legitimasse os "ressentidos nacionais", e o Brasil era potente demais para entrar na tendência "esquizofrênica" da Argentina.

Outra estratégia utilizada pelo jornal para legitimar e convencer seus leitores de que os argentinos eram pessoas inferiores consistia em publicar trechos de editoriais da grande imprensa internacional, sobretudo do The New York Times, bem como artigos originários de Londres, que analisavam a situação em termos dicotômicos como democracia versus ditadura, civilizados versus incivilizados. O jornal também trazia a 
opinião de grandes intelectuais estrangeiros para comentar a crise anglo-argentina. Esse é o caso da publicação de um artigo de Raymond Aron, em que o filósofo francês comparava a repercussão da guerra nos dois países contendores:

O golpe de força despertou o entusiasmo popular na Argentina. Governantes e governados, homens, de direita e de esquerda mantém, após um século e meio, o protesto contra a "invasão britânica", a unanimidade do povo argentino é tal que Adolfo Pérez Esquível, Prêmio Nobel da Paz em 198I, se manifestou em Washington a favor de seu país, cujo regime ele combate. Os argentinos da oposição não se unem provisoriamente a uma política, mas ao governo, que responde a uma velha ambição nacional.

$\mathrm{Na}$ Câmara dos Comuns, membros do Parlamento fizeram manifestações que, a rigor, nada deviam as que reboavam em Buenos Aires. O desafio devia ser rechaçado, a humilhação vingada com sangue. A excitação parlamentar aparentemente não se comunicou à população. Depois do fogo de palha do fervor patriótico, os ingleses retornam a suas ocupações e saem de férias, aprovando a firmeza da Dama de Ferro. ${ }^{43}$

Embora o comentário a respeito da repercussão do conflito para a população dos dois países tenha sido preciso, a escolha do Jornal do Brasil de traduzir e publicar esse artigo nem de longe pode ser considerada uma ação desinteressada, sobretudo se levarmos em conta as ideias políticas e econômicas de Aron. No conjunto das demais publicações, esse artigo causa um efeito de legitimação daquilo que vinha sendo veiculado nas páginas do jornal, sobretudo porque se tratava de uma voz estrangeira e intelectualizada, e, na comparação, a escolha dos termos colaborava para isso: enquanto o Jornal do Brasil fazia o papel de construir a imagem dos argentinos como "nacionalistas fanáticos", como bem foi empregado em alguns editoriais, colunas e artigos, Raymond Aron representava os ingleses como portadores de um "fervor patriótico", criando, portanto, uma percepção simbólica muito distinta para as respectivas manifestações. Essa estratégia foi levada mais adiante, quando o Jornal do Brasil publicou, em um informe, um pequeno texto de Ernesto Sábato. Vejamos:

Do conhecido escritor argentino Ernesto Sábato, autor de Sobre Heróis e Tumbas, sobre os argentinos:

"Herdeiros, por um lado, da cultura latina e francesa, mas descendentes de um país como a Espanha que, como toda a periferia bárbara da Europa não teve um Renascimento no sentido estrito, racionalista e científico, criados em um continente novo e desmesurado, estamos melhor dotados para sentir e compreender Dostoiévski, Kierkegaard, Strindberg, Nietzsche e Kafka. De modo que se não servíssemos para outra coisa, pelo menos serviríamos para facilitar certos europeus a consciência cabal de certos fatos europeus. 


\section{REVISTA ANGELUS NOVUS}

Além disso os bárbaros desempenharam sempre um papel importante face às culturas excessivamente refinadas. Assim aconteceu quando os povos germânicos, ao introduziremse com carretas e cornos de caça no decadente Império Romano, lançaram a semente do gótico e suas catedrais.

A cultura é sempre dialética (não tanto no sentido hegeliano como no sentido kierkegaardiano) e nesse jogo de forças e contraforças a América Latina tem a importância que sempre teve, na formação de uma nova cultura, no primitivismo, na ingenuidade, na paisagem inédita desmedida, na contribuição de um sangue novo e de uma nova perspectiva, e mesmo no ressentimento próprio dos povos inferiorizados. ${ }^{44}$

Reafirmar a nacionalidade de Ernesto Sábato corroborava a ideia de que um argentino falando de outro tinha mais autoridade, portanto, o resultado seria uma percepção verdadeira, além de o jornal ter reivindicado a autoridade do texto escrito por "um conhecido autor". Essa declaração do polêmico Sábato ${ }^{45}$ serviu perfeitamente aos propósitos oportunistas do Jornal do Brasil, pois o texto mencionado, pretensamente erudito, cita diversos teóricos relevantes para sustentar a tese segundo a qual os argentinos, descendentes da "periférica e bárbara" Espanha, eram, consequentemente, "bárbaros”, “irracionais”, “inferiores”, "ressentidos”, "primitivos” e "ingênuos”. Todos esses termos haviam sido utilizados pelo jornal, nas análises empreendidas a respeito dos motivos do conflito ou quando estabeleceu uma comparação entre brasileiros e argentinos, visando demonstrar que as "diferenças linguísticas" engendraram formas distintas de "comportamento" e de "temperamento".

Certamente, na década de 1980, não era nenhuma novidade que as duas metrópoles ibéricas haviam estabelecido, nas Américas, limites não apenas geográficos como também políticos e culturais, e tinham interesses econômicos e sociais particulares para cada região. Contudo, a questão aqui é a forma como o Jornal do Brasil utilizava essa evidência para construir pouco a pouco uma interpretação que considerava inferiores os povos de origem hispânica. Pior, o periódico criava uma continuidade quase orgânica para reforçar não só diferenças evidentes como também

44 Informe JB, Jornal do Brasil, 28/04/1982, p. 6.

45 Ernesto Sábato recebeu críticas bastante irregulares em seu país de origem, embora tenha sido agraciado com elogios por grandes nomes da literatura mundial. Diogo de Hollanda afirma que o autor é pouco estudado nos meios acadêmicos, sendo muitas vezes desdenhado por grandes especialistas na literatura argentina. Uns criticavam a posição política oportunista de Sábato, visto que apoiou grande parte dos golpes de Estado em seu país, outros apenas esvaziavam a importância da sua obra, considerada esteticamente mediana. Contudo, prevaleceu o primeiro tom da crítica. Sua pecha de aliar-se a qualquer governo suscitou a crítica dos seus contemporâneos: Jorge Luis Borges, em entrevista a Bioy Casares, afirmou que Sábato "escreveu pouco, mas esse pouco é tão vulgar que nos sufoca como se fosse uma obra copiosa”; Ricardo Piglia relatou que foi um "tipo de escritor com posições políticas muito oportunistas, muito exibicionista, antipático e muito arrogante"; para Osvaldo Bayer, tratava-se de um "legítimo representante da classe média que sai às ruas só para aplaudir o governante da vez". Essas são apenas algumas das declaraçóes que mostram o quanto era polêmica a figura de Sábato. HOLLANDA, D. "Ernesto Sabato entre a glória e o desprezo". In.: Revista Garrafa, v. 9, n. 27, pp. I-4, 20II. 
para construir preconceitos na intenção de, como sublinha Maria Lígia Prado, apresentar o passado histórico como legitimador do presente. ${ }^{46}$ Vejamos mais um editorial em que o Jornal do Brasil fez a mesma operação, levando a fundo sua interpretação a respeito de "comportamentos" e de "temperamentos":

O Brasil e os brasileiros sentem-se solidários com as famílias argentinas que choram os seus mortos. Sempre há um dever de solidariedade imediata para com quem vive ao nosso lado. Mas trata-se de uma solidariedade humana - e não de um pacto emocional. Não temos por que ser solidários com os erros sucessivos cometidos pelo Governo de Buenos Aires, que arrastou o seu país para um impasse político, econômico - e agora, certamente militar.

Nossa formação não é exatamente a dos povos de língua espanhola deste continente e é por isso que a idéia de uma América Latina só faz sentido, realmente, a vista de uma América Saxônica. Numa primeira comparação de temperamentos, é fácil ver que nos deixamos levar menos facilmente pela retórica florida ou exaltada: ao brasileiro não se negará uma forma peculiar de humor, que desconfia do exagero.

É contra o exagero e o passionalismo que o Brasil deve advertir, sempre que possível, os seus vizinhos hispânicos.

(...)

Mas o Brasil já não tem condições de estimular aventuras. Menos pelos laços econômicos e financeiros que o ligam aos principais centros internacionais, do que pelo fato de que é um país que amadureceu em diversos setores, e que conhece o preço da imaturidade ou da simples incompetência. ${ }^{47}$

Desde o começo de maio de 1982, somou-se à diminuição da mobilidade argentina, imposta pelo bloqueio aeronaval, o bombardeio do aeroporto em Port Stanley/Puerto Argentino, imprescindível ponte aérea a partir do continente. ${ }^{48}$ Isolados, os argentinos tinham pouco a fazer a não ser esperar que definitivamente os britânicos invadissem. No dia is de maio, um comando inglês arruinou a esquadra de aviões IA-s8 Pucurá, localizada ao norte da Grande Malvina, e no dia 2I os britânicos desembarcaram no Porto São Carlos, consolidando a ocupação do litoral e assegurando o acesso para o desembarque na capital. No dia 24 de maio, mais sete aeronaves argentinas foram destruídas e no dia seguinte o bombardeio causado pelo destróier britânico HMS Coventry levou a mais 20 mortes. Assim, no dia 25 de maio, quando a guerra estava

46 PRADO, M. L. C. “O Brasil e a distante América do Sul”. In.: Revista de História, São Paulo, n. I45, pp. I27I49, 2 OOI.

47 Editorial: "Exaltação da Guerra”, Jornal do Brasil, 25/o5/1982, p. Io, grifos nossos.

48 O bombardeio do aeroporto de Port Stanley/Puerto Argentino, em Io de maio, atingiu em cheio a mobilidade argentina, pois a maior eficácia dos militares residia exatamente nos combates aéreos ou aeronavais, uma vez que o nível tecnológico, a qualificação e o profissionalismo dos pilotos argentinos assemelhavam-se aos dos britânicos. Essa forma de combate reduzia as desvantagens da ausência de comando unificado e das falhas de coordenação, pois permitia a ação de pequenas equipes e iniciativas individuais. NOVARO; PALERMO, op. cit., p. 598 . 


\section{REVISTA ANGELUS NOVUS}

caminhando para seu desfecho e a Argentina oferecia poucos riscos, o Jornal do Brasil diminuiu gradualmente a intensidade das suas críticas e passou a minimizar a histeria inicial de ameaça à ordem internacional. Para o periódico, nesse momento existia um "dever de solidariedade imediata" dos brasileiros para com os argentinos, entretanto, sustentava ser uma solidariedade humana e não emocional, porque os brasileiros, "mais amadurecidos em diversos setores", mais racionais e mais astutos, deveriam "iluminar" seus vizinhos hispânicos a respeito dos riscos do "exagero" e do "passionalismo" em que estavam imersos. Se nesse editorial o jornal justificou o distanciamento do Brasil em relação à Argentina menos em função dos "laços econômicos e financeiros que o ligam aos principais centros internacionais, do que pelo fato que é um país que amadureceu em diversos setores", no editorial do dia seguinte, despido o manto da solidariedade, se contradisse e voltou a defender seus principais interesses:

A seqüência possível de tudo o que vier a acontecer daqui por diante colocou para o Brasil um problema infinitamente mais importante que as das suas relações com a África Negra, com o Terceiro Mundo, etc.

Trata-se de ter em mente que o futuro natural do Brasil, dos seus projetos de desenvolvimento, passa por suas relaçóes com a Europa, com os Estados Unidos, com o restante do mundo desenvolvido. Em política externa, as opções decisivas não são propriamente - ou fundamentalmente - geográficas: são políticas. É fácil verificar ou entender que as melhores perspectivas para o Brasil são inseparáveis do seu relacionamento com o mundo desenvolvido. Só nesse contexto um país em contínua evolução poderia encontrar os desafios e as oportunidades que geram novos desenvolvimentos. ${ }^{49}$

Aqui o jornal invocou mais uma vez o "futuro natural do Brasil", típico das grandes potências, destinadas a serem grandes; e o próprio título do editorial, "Definição Essencial”, mostra como o periódico começava a tirar lições da guerra: nessa "definição", os governantes brasileiros deveriam entender que se tratava de uma ilusão manter prioritárias as relações com a África Negra ou com o Terceiro Mundo, e para o Jornal do Brasil a Argentina pertencia ao último grupo, tão estigmatizado. Esse desdém, sem dúvida alguma, valia para os acordos estabelecidos entre Brasil e Argentina nos últimos dois anos, sobretudo porque desde o final do ano de i980, o Jornal do Brasil via com desconfiança a aproximação e o tom das negociações entre os dois países. Assim, segundo o periódico, para que o Brasil cumprisse seu "destino manifesto", deveria aliarse somente aos grandes, aos Estados Unidos e à Europa homogênea. No dia 5 de junho, o jornal voltou a defender, em editorial, esta mesma pauta, vejamos: 
De tudo isto, o que ressalta é a necessidade urgente de, apagadas as labaredas mais fortes do conflito, dar início a uma nova etapa no relacionamento continental - em que o enfoque generalizante já não será de qualquer utilidade, pois foi atropelado pelos fatos.

Seu defeito mais óbvio é o de impedir verdadeiras relações de Estados a Estados, truncando a especificidade de cada país - e quase se poderia afirmar que em vez de uma América Latina, há tantos quantos são os países que ela integra. Como sustentar, por exemplo, que a atual realidade econômica, social e cultural do Brasil assemelha-se a deste ou daquele país contíguo, ou que a experiência de desenvolvimento brasileiro tenha algo a ver com o que se pratica no Peru e no Equador?

(...)

Há um fato que não deve ser esquecido: no Brasil, não há sentimento popular antiamericano, tal como ele tende a existir no México ou na América Central e na maioria dos países da América do Sul - decorrência inevitável da proximidade geográfica, de contendas antigas ou recentes. $\mathrm{O}$ antiamericanismo que às vezes se chega a identificar por aqui é antes fenômeno esporádico, de motivação sobretudo ideológica. Não existe nem passou a existir por causa desta guerra - o que já não será possível afirmar em relação à Argentina, ou menos a países como o Peru e a Venezuela arrastados inexplicavelmente pelo temporal de paixões surgido em Buenos Aires.

Como país que amadurece, o Brasil tem todo o interesse em enfocar a sua realidade geográfica e continental à luz de um mínimo de pragmatismo; e esse mínimo manda reconhecer que ignorar a presença norte-americana no continente é praticar uma curiosa forma de fantasia mental.

Mas o Brasil também tem todo o interesse em ser analisado e compreendido à luz da sua própria realidade, da sua realidade de hoje - e não no bojo de uma visão abrangente que só enxerga grandes blocos e "focos mundiais de poder" definidos muitas vezes de forma bastante acadêmica. Em termos de política externa norte-americana, esta percepção exigirá uma nítida ruptura com o passado - com o passado que a guerra das Falklands mandou para o fundo do Atlântico..$^{\circ}$

Havia a correta percepção de que as relações interamericanas saíram profundamente abaladas pela crise anglo-argentina, sobretudo por conta do apoio direto dos Estados Unidos à Grã-Bretanha e por se verem minguadas as possibilidades de um país americano acionar os mecanismos de defesa criados pelos próprios Estados Unidos. Acima de tudo, o enfoque generalizante era a suposição de que os países latinoamericanos esperavam a proteção e a tutela irrestritas dos Estados Unidos, e é exatamente por essa suposição que o periódico rejeitava inserir o Brasil no conjunto desses países, pois o Brasil tinha existência independente, progredia em uma realidade fora de "grandes blocos", muito embora o jornal considerasse a manutenção das relações com os Estados Unidos imprescindíveis. E aqui o periódico quis reforçar mais

Editorial: "Ilusão Latino-Americana”, Jornal do Brasil, o5/o6/1982, p. Iо. 


\section{REVISTA ANGELUS NOVUS}

uma diferença entre brasileiros e a "massa" latino-americana: os brasileiros, por serem "mais amadurecidos em diversos setores", não possuíam o sentimento antiamericano dos demais países. O Brasil, ademais, não podia ser inserido no conjunto da América Latina por conta dos diversos atributos que não compartilhava com seus vizinhos hispânicos, atributos esses que poderiam ser sintetizados em "comportamento" e "temperamento". Para o Jornal do Brasil, a Guerra das Malvinas serviu, apesar das intempéries, para apresentar a verdadeira conduta de todos os países envolvidos no conflito. A respeito dos países de origem hispânica, o periódico compreendia os respectivos envolvimentos não como a política de um determinado governo, mas como ação naturalizada e generalizada desses povos. Além disso, a guerra deveria inaugurar um novo tempo nas relações interamericanas, na medida que esses Estados compreendessem a necessidade de se fazer uma política autônoma e meritória.

Por fim, vejamos trechos dos dois últimos editoriais lançados pelo Jornal do Brasil diretamente relacionados ao conflito:

No imprevisível futuro que acaba de abrir-se com o fim da guerra e da derrocada do Governo Galtieri, a Argentina estaria, segundo alguns indícios, sob a tentação de ampliar a sua abertura para o lado soviético, como compensação instintiva de uma suposta traição norte-americana.

(...)

A Argentina, entretanto, nunca se identificou com esta liderança militar que a conduz à catástrofe.

E, tornada agora ainda mais nítida a diferenciação entre a nação e o regime, seria importante que a própria nação manifestasse o seu inconformismo ante um tipo de represália do regime militar que seria a troca da amizade norte-americana pela submersão nos "mares soviéticos". Pois a humilhação da derrota militar recai sobre o regime, e não sobre a própria Argentina."

De início, o conteúdo desse editorial pode parecer contraditório com o que dissemos acima. Todavia, dialogando diretamente com seus possíveis leitores argentinos, o Jornal do Brasil, paliativamente, mudava seu discurso na intenção de convencer esses indivíduos de que radicalizar a abertura para o "lado soviético" não era um bom negócio. O jornal, assim, estava defendendo intimamente seus principais interesses:

O Brasil teve uma atuação serena ao longo de todo este lamentável episódio da História sul-americana. Tem, assim, todas as condições de aproximar-se agora de um vizinho que atravessa uma conjuntura dificílima, e de fazer todo o possível para atenuar essas dificuldades. 
Não se trata apenas de um apoio moral: a Argentina é um dos principais parceiros do Brasil; e neste sentido depende tanto do Brasil quanto o Brasil depende da Argentina. Uma postura ativa do Brasil em suas relações comerciais com a Argentina passou a ser, assim, não apenas uma medida filantrópica ou amigável, mas uma política indispensável ao equilíbrio econômico de toda a região.

Esta ajuda brasileira tem um outro sentido transcendente: o de auxiliar a Argentina a reagir contra o ressentimento a que eventualmente poderiam conduzi-la lideranças pouco esclarecidas, ou as próprias conseqüências de uma guerra que apenas terminou. Sabe-se o que é capaz de fazer, neste terreno, o ressentimento: a Alemanba derrotada de 1918 não cessou de alimentar a ambição da desforra, e assim a Europa foi lançada a um outro conflito generalizado. ${ }^{22}$

O Brasil deveria se aproximar da Argentina a ponto de impedir que um governo de esquerda/comunista se instaurasse no país ao lado, impedindo que os riscos prognosticados desde o início se concretizassem. Isso levaria a um retrocesso imenso, revertendo os resultados preciosos e tão caros que as ditaduras implantadas "por emergências mundiais ou locais” haviam alcançado, ou seja, expurgar esses indivíduos do centro de decisões. Nesse sentido, o Jornal do Brasil se manteve coerente em suas perspectivas de reinserir o Brasil nos centros de poder, acreditando que os anos fizeram desse país uma "potência natural” e predestinada a se manter entre os "grandes" do Ocidente.

\section{Considerações finais}

Neste artigo, procuramos analisar as interpretações construídas pelo Jornal do Brasil a respeito do posicionamento e da participação dos demais países latinoamericanos no conflito, assim como acerca da possibilidade de interferência soviética na crise. Todo o empreendimento do periódico se deu mediante o contraste entre um Brasil civilizado e civilizador e a "outra” América, conjunto composto por hispânicos que recusaram a marcha do progresso e permaneceram estagnados com os problemas fundamentais do século XIX, como o caudilhismo. Nessas discussões, há uma contradição sensível: o periódico fez uso recorrente de apelos sentimentais para se aproximar de seu público ao mesmo tempo que pretendia deslegitimar seus vizinhos hispano-americanos por serem demasiadamente "passionais". Todavia, se atentarmonos, veremos que essa contradição é apenas aparente. Certamente, o Jornal do Brasil entendia o peso e a natureza da sua retórica, contudo, não via tais aspectos como problemas, pois se tratava de uma empresa privada que tinha finalidades específicas: lucrar e dissuadir; muitas vezes, também, apresentava-se como um pedagogo dos menos 


\section{REVISTA ANGELUS NOVUS}

ilustrados. O que não considerava tolerável era um governo tomar suas decisões nesses termos. Para isso reivindicava uma perspectiva culturalista que partia de uma generalização que considerava bárbaros todos aqueles nas Américas que descendiam dos espanhóis.

Era preciso convencer os brasileiros e o restante do mundo que o Brasil não compartilhava nada com seus vizinhos, pois possuíam diferenças substanciais de "comportamento" e de "temperamento". O periódico não explicou os pormenores desses conceitos; entretanto, alguns indícios foram levantados: primeiro, a atitude do governo brasileiro em relação ao conflito era considerada a mais adequada, pois assumiu uma posição de neutralidade em oposição à reivindicação de apoio de uma grande parcela dos países latino-americanos; segundo, o jornal escreveu que o Brasil há muito tempo era um país viável, pois não se sujeitava a "políticas tutelares", em contraste com os hispano-americanos que estabeleciam com as grandes potências uma relação "paternalista"; terceiro, o Brasil possuía uma "rota natural" que o alocava sempre ao lado dos valores ocidentais, ao passo que os hispano-americanos assumiam posições dúbias, ora condenando o comunismo, ora barganhando o apoio dos países comunistas.

Dessas características elencadas pelo periódico, todas foram severamente deturpadas: primeiro, a neutralidade adotada pelo governo brasileiro, como se disse, foi de caráter imperfeito, ou seja, pendia para os interesses argentinos, e nem todos os países latino-americanos reivindicaram apoio direto aos argentinos. Não podemos deixar de mencionar, ademais, que o periódico procurava formas sutis de criticar as decisões da chancelaria brasileira, muitas vezes dissociando-as da figura do Executivo; segundo, o Brasil esteve sujeito a políticas tutelares ao longo de todo o período republicano, dependendo do capital estrangeiro tanto ou mais do que seus vizinhos hispânicos, e esteve alinhado às principais decisões norte-americanas nos fóruns internacionais. O terceiro item talvez se aproxime um pouco mais da realidade brasileira, pois, na maior parte de sua história, o Brasil esteve alinhado ao centro de interesses dos países do norte, possuía uma cultura política autoritária e uma forte tradição anticomunista, realidade que nada tinha de "natural” e não diferia muito daquela experienciada nos vizinhos hispânicos, sobretudo aqueles que viviam sob o signo das Ditaduras de Segurança Nacional.

É preciso dizer, ademais, que o Jornal do Brasil escolheu, em benefício dos seus interesses, não se omitir dos debates a respeito da redemocratização no Brasil e no Cone Sul: o novo regime deveria ser uma república com amplas liberdades econômicas e participação política reduzida, sobretudo no Brasil. Se as representações negativas do 
periódico em relação aos vizinhos se alteraram radicalmente após a insustentabilidade da resistência argentina nas Malvinas, foi porque acreditava que a derrota geraria uma humilhação nacional e, consequentemente, sentimentos de repúdio aos Estados Unidos e às velhas potências ocidentais, facilitando a organização e a ascensão de governos esquerdistas/comunistas. Para o pós-guerra, o Jornal do Brasil dialogou diretamente com a população platina e suas elites políticas, assim como com as brasileiras, pois era preciso convencer os argentinos de que a humilhação não era da nação, mas dos militares.

Retomamos, por fim, o editorial publicado no dia 07/04/1982, intitulado "Fantasmas do Passado", para traçar algumas considerações a respeito do modelo explicativo adotado pelo periódico em suas análises dos mais variados assuntos pertinentes às histórias do Brasil e da Argentina; mais especificamente, trata-se da concepção de tempo proposta pelo Jornal do Brasil.s3

Duas questões chamam a atenção nesse editorial: primeira, que o caudilhismo foi entendido como um fenômeno intermitente do século XIX até a data da publicação do editorial; segunda, trata-se do papel conferido ao ex-presidente argentino, o liberal Domingo Faustino Sarmiento, e suas relações com o caudilho Juan Manuel de Rosas. Para compreender essas duas questões, é preciso ter em mente que essa discussão remonta à organização do Estado Nacional argentino, em que, de forma bastante simplificada, dois principais grupos políticos disputavam um modelo de Estado: unitários e federalistas. Sarmiento fazia parte do primeiro grupo, que propunha a união das províncias e a centralização do poder; no que se refere a Rosas, este advogava que as províncias se mantivessem autônomas até que se organizassem internamente para, em seguida, comporem uma Federação. Certamente, o modelo endossado pelo Jornal do Brasil era o defendido por Sarmiento, por isso, é preciso compreendê-lo melhor.

O "grande argentino" ao qual o jornal se refere começou a publicar, em I845, em formato de folhetim, a também citada obra Facundo, ou civilização e barbárie. Trata-se, sem dúvida, de um texto que alcançou uma notoriedade muito grande ao longo da história argentina, e os debates a respeito do conteúdo e do gênero dessa obra são inúmeros: a classificação vai de romance a ensaio sociológico. Seja como for, Maria Ligia Prado escreve que Sarmiento inaugurou com essa obra um modelo interpretativo que ultrapassa a simples análise-biografia da vida do caudilho Facundo Quiroga, uma vez que propôs o diagnóstico da sociedade argentina como um todo ${ }^{54}$. As dicotomias

\footnotetext{
53 Cf.: supra, nota 30.

54 PRADO, M. L. C. "Para ler o Facundo de Sarmiento”. In: PRADO, Maria Lígia Coelho. América Latina no século XIX: Tramas, Telas e Textos. São Paulo: Editora Universidade de São Paulo, 2004. pp. I5I-I77.
} 


\section{REVISTA ANGELUS NOVUS}

alocadas no texto foram recuperadas ao longo da história por diversos indivíduos que viam nas explicações de Sarmiento um bom caminho para interpretar os problemas estruturais da Argentina. Sarmiento, assumindo-se como herdeiro das "luzes”, escreveu na terceira parte de sua obra uma proposta alternativa para a organização do Estado Nacional argentino, prescrevendo, também, a queda de Rosas. Maria Ligia Prado sintetizou os principais itens, vejamos:

Continuando a tomar pares opostos, Sarmiento afirmava que o novo governo garantiria as fronteiras do sul contra os índios, estabelecendo colônias militares na região; incentivaria a imigração, povoando o interior "deserto"; fomentaria a navegação fluvial, tornando livres todos os rios. Buenos Aires seria declarada propriedade nacional, e suas rendas promoveriam o bem-estar da nação; a educação pública seria organizada para que a Argentina entrasse para o rol dos países civilizados; promoveria a imprensa livre e a publicação de jornais e livros; o novo governo se rodearia de grandes homens ilustrados, que estavam esparramados pela terra, e a inteligência, o talento e o saber seriam chamados de novo a dirigir os destinos do país; restabeleceria formas representativas de governo e, finalmente, haveria justiça. O novo governo seria amigo dos povos europeus e simpático aos povos americanos. Tudo isso "porque Deus nos deu [as luzes da] razão que nos distinguem das bestas e nos tornam livres para julgar." "s

Embasado na doutrina liberal, todo o texto de Sarmiento estava calcado em dicotomias, contudo, nesse caso, propunha uma diferenciação substantiva entre as "trevas" do presente e o "esplendor" do futuro sob a égide do seu governo. Ao pretender excluir uma parcela significativa da sociedade argentina para a efetivação de seu projeto civilizador, "Facundo, como uma das 'ficções-guias' argentinas, deve ser entendido como uma 'mitologia de exclusão', e não como uma idealização da unidade nacional” ${ }^{56}$ Não é nosso foco aqui, mas esta sentença proferida por Maria Ligia Prado convida-nos a refletir a respeito das noções que advogam uma imprevisibilidade e uma legitimidade irrefutável da adoção do modelo liberal como o único capaz de organizar o Estado-Nação argentino na segunda metade do século XIX. Nesse sentido, o Jornal do Brasil valorizava duplamente a figura de Sarmiento: primeiro, porque atualizava o modelo explicativo maniqueísta elaborado pelo argentino para explicar a contemporaneidade do país platino; segundo, porque o modelo de Estado-Nação proposto pelo liberal argentino era indubitavelmente próximo do modelo defendido pelo periódico. 
Quando o jornal escreveu que: "Condenado à morte por Rosas, Sarmiento conheceu o pior aspecto do caudilhismo e sonhou com uma Argentina que se evoluísse no sentido institucional”, de imediato, podemos interpretar o seguinte trecho de duas maneiras: ou como uma deturpação do sentido literal; ou como uma metáfora que propõe a inviabilização de uma "grande Argentina" após a derrocada do projeto liberal, que só aconteceu, entretanto, em fins da segunda década do século XX. Ambas as possibilidades se mostram bastante problemáticas, mas trabalham para o mesmo fim. A construção ambígua e pouco detalhada do trecho não permite que o leitor com conhecimento histórico médio compreenda quando, como e se efetivamente Sarmiento morreu por conta dessa condenação. Assim, se a interpretação pender para o sentido literal, trata-se de uma deturpação na medida em que Sarmiento, embora tenha sido preso e condenado à morte, conseguiu fugir para o exílio no Chile. Todavia, o restante do trecho não nos permite ter conhecimento dessa evidência e a conclusão do trecho se deu de forma melancólica, afirmando que o argentino apenas "sonhou com uma Argentina que se evoluísse no sentido institucional”. Nesse sentido, Sarmiento é retratado como mártir da causa nacional e vítima do caudilhismo.

Se a interpretação, contudo, pender para o sentido metafórico, a ideia que temos é que o caudilho Juan Manuel de Rosas definiu toda a história argentina e impediu a implementação do projeto liberal de Sarmiento, quando sabemos hoje que o modelo liberal de organização do Estado na Argentina vigorou predominantemente de meados do século XIX até fins da segunda década do século XX, quando novas direitas emergiram no cenário político argentino propondo distintos diagnósticos que se assemelhavam, entre outros aspectos, na responsabilização das oligarquias liberais como profanadoras do espírito nacional argentino ${ }^{57}$. De todo modo, as duas abordagens sugerem que o caudilhismo, ou melhor, a figura de Rosas, impediu que o "grande" argentino, Sarmiento, pudesse concretizar uma Argentina civilizada e institucionalizada, e que, necessariamente, a ditadura do Proceso e a Guerra das Malvinas eram sintomas desse processo.

57 José Luis Bendicho Beired diagnostica, no período entreguerras (1914-1945), a emersão de uma nova direita nacionalista autoritária no Brasil e na Argentina que propunha diagnósticos para a crise que acometera o sistema liberal, em princípio pelo desenvolvimento da Primeira Guerra e, posteriormente, pela crise econômica mundial de 1929. Esses indivíduos, intelectuais em sua maioria, provenientes das tradicionais classes dirigentes, intervinham na agenda pública a partir da publicação em jornais, livros, revistas, associações políticas, religiosas e ligas militarizadas. Possuíam, sim, diferenças significativas em relação à abordagem, contudo, um dos traços marcadamente comum entre todos esses indivíduos é que possuíam "um componente acirradamente antiiluminista que combatia o modo de pensar, os valores e as ideologias de emancipação que marcaram a emergência da modernidade”. Nesse sentido, baseando-se num critério realista de análise do mundo, propunham uma diferenciação entre o "país legal, artificial" e o outro "país real, essencial”. Em suma, a ideologia liberal era apontada como responsável pela desfiguração dos respectivos países, pois impunha "valores e uma ordem institucional contrária as realidades locais". BEIRED, J. L. B. Sob o signo da nova ordem: intelectuais autoritários no Brasil e na Argentina (1914-1945). São Paulo: Edições Loyola, 1999, p. 97. 


\section{REVISTA ANGELUS NOVUS}

É ainda mais correto afirmar que a explicação proposta pelo periódico a respeito do século XX argentino foi toda fundamentada no seu diagnóstico do caudilhismo enquanto patologia, assim, Rosas, os sucessivos golpes militares, Perón e a Guerra das Malvinas eram explicados a partir de uma continuidade secular, uma progressão que não abre brechas a rupturas. Essa concepção de tempo adotada pelo Jornal do Brasil era perfeitamente coerente, também, com suas análises empreendidas a respeito da história do Brasil. Se o periódico propõe a atualidade da leitura de Sarmiento e dos liberais argentinos do século XIX para explicar todos esses processos é porque, em grande medida, compartilha e propõe-se herdeiro dos elementos fundantes da identidade nacional brasileira baseados em uma tradição iluminista.

Se o Estado Nacional brasileiro, consolidado na segunda metade do século XIX, vincou sua tarefa de continuador do processo civilizador iniciado com a colonização portuguesa,$^{58}$ nos anos seguintes veremos a manutenção dessa percepção, embora a identidade nacional como um todo tenha sofrido mutaçóes bastante significativas. Basta lembrarmos, a respeito disso, a intermitente disputa brasileira com seus países vizinhos para firmar sua hegemonia na região, ou os períodos em que essa característica se acentuou ainda mais, quando do amplo crescimento econômico da década de 1950 ou com a ideologia "Brasil grande potência" no governo ditatorial de Emilio Garrastazu Médici (1969-1974). No lugar privilegiado de discutir e de definir a nação brasileira, os indivíduos que compuseram o Instituto Histórico e Geográfico Brasileiro (IHGB) deliberaram e definiram não só aqueles que internamente ficariam fora da denominação de "civilizados", negros e indígenas, como também aqueles que externamente seriam associados à "barbárie": as repúblicas hispano-americanas. 59

Pelos diversos motivos mencionados, o Jornal do Brasil via em Sarmiento um grande ideal e aliado para endossar sua leitura histórica. Não é demais lembrar que o argentino também acreditava numa tradução do mundo civilizado do Norte para o americano, guardadas as respectivas particularidades do seu espaço-tempo. Do modelo explicativo engendrado, podemos concluir que o periódico elencava o caudilhismo como fenômeno determinante de todo o curso histórico argentino, e este país só poderia ter tido um destino diferente se o projeto liberal, sobretudo o de Sarmiento, ainda perdurasse. Se nos anos 80 do século XX a Argentina ainda era produto da barbárie, o reacionário jornal brasileiro se apresentava, por outro lado, como porta-voz dos interesses mais amplos da humanidade, na medida em que afirmava que o Brasil 
concluiu seu curso do progresso, portanto, deveria ser tomado como um país "viável", a “caminhar com suas próprias pernas” e a auxiliar no curso civilizador dos seus vizinhos hispânicos. 